\title{
Comparative Ameliorative Efficacy of Tamarind Pulp against Boron on Fluorotic Calves Reared in Periphery Villages of Aluminium Smelter Plant
}

\author{
Mirashree Pati ${ }^{1}$, Ghana Syam Parida ${ }^{1}$, Kruti Debnath Mandal ${ }^{1,2 *}$, \\ Amit Raj Gupta ${ }^{1,3}$ and Ramesh Chandra Patra ${ }^{1}$
}

${ }^{1}$ Department of Veterinary Clinical Medicine, Ethics And Jurisprudence, College of

Veterinary Science and Animal Husbandry, Orissa University of Agriculture and

Technology, Bhubaneswar-751003, Odisha, India

${ }^{2}$ Department of Veterinary Clinical Complex, Faculty of Veterinary and Animal

Sciences, RGSC-BHU, Barkachha, Mirzapur, Uttarpradesh, India

${ }^{3}$ Department of Veterinary Medicine, Ethics and Jurisprudence, West Bengal university of

Animal and Fishery Sciences, WB, India

\author{
*Corresponding author
}

\section{A B S T R A C T}

\begin{tabular}{|l|}
\hline Ke y w or d s \\
$\begin{array}{l}\text { Tamarind, } \\
\text { Fluorosis, Calf, } \\
\text { Aluminium smelter } \\
\text { plant }\end{array}$ \\
\hline Article Info \\
\hline $\begin{array}{l}\text { Accepted: } \\
11 \text { June } 2020 \\
\text { Available Online: } \\
10 \text { July } 2020\end{array}$ \\
\hline
\end{tabular}

\section{Introduction}

Fluorosis is observed in areas with high levels of Fluoride $(\mathrm{F})$ in ground water (Choubasia 1999) or in areas where industrial wastes contaminate water, soil and vegetation (Ergun et al., 1987). Smelting of aluminium ore is an important source of $F$ emitted to the environment in gaseous and particulate form (Swarup et al., 1998). The disease is mainly
The aim of this investigation was to carry out thecomparative therapeutic study on fluorotic calves reared in vicinity of an aluminium smelter plant. The F burden in the environmental samples (soil, fodder and water) collected from the vicinity of aluminium smelter was significantly higher than that of non-fluorotic zone. Significantly higher level of $\mathrm{F}$ was also recorded in plasma, urine and faecal samples which were associated with significant alterations in haemato-biochemical parameters in the F-exposed calves compared to the calves reared in non-fluorotic area. Supplementation of tamarind pulp in the feed significantly altered the $\mathrm{F}$ level in plasma, urine and faeces in the exposed calves along with restoration of haemato-biochemical parameters by day 60 in comparision to the routinely used F-binding agent (Boron) which proved its better efficacy against the development and/or progression of fluorosis. characterized by brown discolouration, hypomineralisation, and increased attrition of teeth, bony exostosis, lameness and painful gait (Patra et al., 2000). Calves exhibited the highest prevalence of fluorosis as they are more sensitive and susceptible and less tolerant to fluoride (Shupe 1980) and also due to their rapidly growing skeleton. Curative treatment is always futile once the skeletal lesions are prominent. Management measures 
aimed at preventing fluorosis in cattle reared in areas with endemically high environmental $\mathrm{F}$ levels are only fruitful during early stages of life (during calfhood). Aluminium (Al), calcium (ca), boron (B), selenium (Se) and some hormones have been evaluated for mitigation of fluorosis with variable success rates (Kessabi et al., 1986; Han and Shi 2001; Maiti and Das 2004). Most are unfit for therapeutic purposes due to side effects upon prolonged use. Tamarindus indica L. (Tamarind) has been reported to exert a beneficial effect on $\mathrm{F}$ toxicity (Khandare et al., 2000). In the present study, the prophylactic efficacy of dried powder of tamarind pulp as an ameliorative agent in comparison to standard chemical antidotes is investigated in calves with natural fluorosis for the first time.

\section{Materials and Methods}

\section{Study site}

The study was conducted within the $5 \mathrm{~km}$ radius of an aluminum smelter plant at Angul, Odisha, (latitude $20^{\circ} 95{ }^{\prime} \mathrm{N}$ to $21^{\circ} 10^{\prime} \mathrm{N}$ and longitude $84^{\circ} 55^{\prime} \mathrm{E}$ to $85^{\circ} 28$ 'E) and $150 \mathrm{~km}$ away from Bhubaneswar, the state capital of Odisha, India.

\section{Animals and experimental protocol}

Eighteen fluorotic calves of 6-10 months old, born and reared within the $0-3 \mathrm{~km}$ radius from the smelter, having average of $81.2 \mathrm{~kg}$ body wt with visible signs of dental fluorosis such as deep yellow and brown discolorations, linear pigmented vertical streaks, loss of luster, attrition and mottling of teeth with or without pitting, were selected randomly from different properties without any clustering and were divided into 3 equal groups with 6 animals each. The calves were mostly maintained on grazing with supplementation of locally harvested paddy straw $(1 \mathrm{~kg})$ as daily ration for 60 days. Among them, one group served as disease control without any treatment. The second group was supplemented by tamarind pulp powder (daily receiving orally $30 \mathrm{~g} / \mathrm{animal}$ ). The third group received daily $5 \mathrm{~g}$ /animal boric acid (Merck ltd, kolkata, India). Calves (6-10 months old with mean age of 8 months), living in Bhubaneswar (an area with low environmental $\mathrm{F}^{-}$level) served as the negative control.

\section{Collection of samples}

Water samples, soil samples and fodder samples (dry and green) were collected from different sources from the polluted area following standard protocol. Blood, urine and faecal samples were collected from each animal between 6 - 8 A.M. on day 0,30 and 60.

\section{Estimation of fluoride}

$\mathrm{F}^{-}$concentrations were estimated by ion specific potentiometry using total ionic strength adjustment buffer and a portable $\mathrm{F}$ specific electrode (Orion model $9409 \mathrm{BN}$, Thermo Fisher Scientific, Waltham, MA, USA), and meter (Orion Model-290A) with detection range between 0.019 and 1900 $\mathrm{mg} / \mathrm{L}$.

\section{Haemato-biochemical parameters}

Haemoglobin concentration $(\mathrm{Hb})$ was determined by Sahli's hemometer and packed cell volume (PCV) was determined by microhaematocrit method. Total leucocyte count (TLC) and differential leucocyte count (DLC) were determined by using the standard reference methods (Benzamin 1985). The activity of Alkaline phosphatase (ALP) and Aspartate transaminase (AST), and the level of urea, creatinine, total protein, $\mathrm{Ca}$ and phosphorus were estimated in plasma samples 
by semi auto analyser (Model no- Microlab 300, Merck, India) using commercial reagent kits supplied by Crest Biosystems, Goa, India.

\section{Statistical analysis}

The data obtained for each parameter were compiled and analyzed using SPSS 22 software for post hoc analysis by Duncan's multiple comparison tests and least square deviation (LSD) to find out the mean, standard error, range and significant difference of mean values between the groups and the paired t-test was conducted for comparisons of the groups within the periods (Day 0, 30 and 60) with $\mathrm{P}<0.05$ considered statistically significant.

\section{Results and Discussion}

The concentration of fluoride in environmental and plasma samples

The $\mathrm{F}$ concentrations in soil, water, fodder and plasma samples in relation to the distance from the plant are shown in table 1 .

\section{Effect of treatment on biological sample}

The plasma, urine and faecal $\mathrm{F}$ concentrations in different groups are given in table 2. The mean $\mathrm{F}$ concentration in the plasma, urine and faecal samples of fluorotic animals at day 0 was significantly $(\mathrm{P}<0.05)$ higher than the corresponding negative control (Group I). The $\mathrm{F}$ concentrations in plasma and urine of the calves treated with $\mathrm{B}$ and tamarind, were significantly lower and the faecal $\mathrm{F}$ levels were significantly $(\mathrm{P}<0.05)$ higher by day 60 compared to day 0 .

However, a greater effect was observed in tamarind-treated calves with a $66 \%$ reduction in plasma $\mathrm{F}$ levels, compared to a $51 \%$ reduction in the B-treated group (Table 3 ).

\section{Haematological parameter}

Table 4 depicts significantly lower level of haemoglobin, TLC and haematocrit value in fluorotic calves than calves from a low $\mathrm{F}$ area and the same increased significantly $(\mathrm{P}<0.05)$ after 60 days of the administration of either B or tamarind, though the rise was significantly higher upon treatment with tamarind than B. The above parameters increased significantly $(\mathrm{P}<0.05)$ towards the end of treatment periods, while during the $1^{\text {st }}$ half both the treatments failed to show any significant improvement.

\section{Plasma biochemical parameters}

Calves from the high $\mathrm{F}$ area had significantly $(\mathrm{P}<0.05)$ lower $\mathrm{Ca}$, total protein and albumin levels, and higher phosphorous, ALP, AST, urea and creatinine levels than calves from the low $\mathrm{F}$ areas. By day 60, treatment with tamarind or B had resulted in a significant $(\mathrm{P}<0.05)$ increase in $\mathrm{Ca}$ and a significant decrease in phosphorous, ALP and AST. Overall, tamarind was found more potent than $\mathrm{B}$ in increasing $\mathrm{Ca}$ and total protein level, and reducing AST, urea and creatinine level than B after the treatment period (Table 3).

\section{Industrial fluorosis and its effect on animal-environment eco-system}

Although, F from industrial sources is mostly ejected to the air, it may cause toxic contamination of soil, water and vegetation in the industrial vicinity (Patra et al., 2000). F in soil and water that is used for irrigation ultimately finds its way into forage and grains and it eventually enters into the food chain of human and animals which has deleterious impact on their health. 
Table.1 Fluoride level (mean \pm SE) in ppm in soil, water and feed samples of Fluoride

\begin{tabular}{|l|l|l|}
\hline Sample & Fluoride polluted area & Unpolluted area \\
\hline $\begin{array}{l}\text { Soil } \\
\text { Water }\end{array}$ & $166.07 \pm 10.49^{\mathrm{b}}$ & $3.3 \pm 0.21^{\mathrm{a}}$ \\
$\begin{array}{c}\text { Surface } \\
\text { Ground }\end{array}$ & $2.34 \pm 0.134^{\mathrm{bB}}$ & $0.11 \pm 0.02^{\mathrm{a}}$ \\
Fodder & $0.731 \pm 0.084^{\mathrm{bA}}$ & $0.19 \pm 0.04^{\mathrm{a}}$ \\
Dry & $186.83 \pm 28.96^{\mathrm{bY}}$ & $2.73 \pm 0.02^{\mathrm{a}}$ \\
Green & $139.75 \pm 5.41^{\mathrm{bX}}$ & $7.15 \pm 0.93^{\mathrm{aY}}$ \\
Milk & $0.13 \pm 0.007^{\mathrm{b}}$ & $0.059 \pm 0.005^{\mathrm{a}}$ \\
\hline
\end{tabular}

Polluted area and Unpolluted area

The values (Mean \pm S.E., $\mathrm{n}=6$ ) with dissimilar superscript (small letter) within a row varies significantly at $\mathrm{p}<0.05$. The significant differences in the mean levels of $\mathrm{F}$ between ground water and surface water tested for different distance range and similar procedure has been done to test the differences in the means between green and dry fodder. Means bearing different superscripts (capital letters) differ significantly at $5 \%$ level $(\mathrm{p}<0.05)$

Table.2 Concentrations of F (ppm) in bio samples of calves from both less exposed and fluorotic area at different observation periods

\begin{tabular}{|l|l|c|c|c|}
\hline Parameter & Group & Day 0 & Day 30 & Day 60 \\
\hline \multirow{3}{*}{ Plasma F } & Group I & $0.084 \pm 0.005^{\mathrm{A}}$ & $0.086 \pm 0.005^{\mathrm{A}}$ & $0.083 \pm 0.003^{\mathrm{A}}$ \\
& Group II & $0.433 \pm 0.018^{\mathrm{B}}$ & $0.449 \pm 0.017^{\mathrm{D}}$ & $0.466 \pm 0.019^{\mathrm{D}}$ \\
\cline { 2 - 5 } & Group III & $0.483 \pm 0.020^{\mathrm{cB}}$ & $0.321 \pm 0.013^{\mathrm{bC}}$ & $0.235 \pm 0.009^{\mathrm{aC}}$ \\
\cline { 2 - 5 } & Group IV & $0.442 \pm 0.017^{\mathrm{cB}}$ & $0.257 \pm 0.029^{\mathrm{bB}}$ & $0.150 \pm 0.016^{\mathrm{aB}}$ \\
\hline \multirow{3}{*}{ Urine F } & Group I & $2.383 \pm 0.230^{\mathrm{A}}$ & $2.342 \pm 0.220^{\mathrm{A}}$ & $2.35 \pm 0.213^{\mathrm{A}}$ \\
& Group II & $10.633 \pm 0.559^{\mathrm{B}}$ & $11.167 \pm 0.526^{\mathrm{D}}$ & $11.533 \pm 0.542^{\mathrm{C}}$ \\
\cline { 2 - 5 } & Group III & $11.717 \pm 0.248^{\mathrm{cB}}$ & $9.917 \pm 0.209^{\mathrm{bC}}$ & $8.4 \pm 0.259^{\mathrm{aB}}$ \\
\cline { 2 - 5 } & Group IV & $10.867 \pm 0.489^{\mathrm{cB}}$ & $8.716 \pm 0.631^{\mathrm{bB}}$ & $7.283 \pm 0.367^{\mathrm{aB}}$ \\
\hline \multirow{2}{*}{ Faecal F } & Group I & $6.471 \pm 0.530^{\mathrm{A}}$ & $6.622 \pm 0.476^{\mathrm{A}}$ & $6.573 \pm 0.194^{\mathrm{A}}$ \\
& Group II & $20.797 \pm 0.767^{\mathrm{B}}$ & $20.95 \pm 0.739^{\mathrm{B}}$ & $21.03 \pm 0.605^{\mathrm{B}}$ \\
\cline { 2 - 5 } & Group III & $21.155 \pm 0.676^{\mathrm{aB}}$ & $24.747 \pm 0.635^{\mathrm{bC}}$ & $26.100 \pm 0.245^{\mathrm{bC}}$ \\
\cline { 2 - 5 } & Group IV & $21.200 \pm 0.665^{\mathrm{aB}}$ & $24.783 \pm 0.510^{\mathrm{bC}}$ & $26.000 \pm 0.369^{\mathrm{bC}}$ \\
\hline
\end{tabular}

The values (mean $\pm \mathrm{SE}, \mathrm{n}=6$ ) bearing no common superscript in small letters in a row and capital letters in a column differ significantly at $\mathrm{P}<0.05$.

Group I: Negative control; Group II: Fluorotic calves; Group III: Fluorotic calves receiving boron; Group IV:

Fluorotic calves receiving tamarind 
Table.3 Comparative efficacy of boron and tamarind treatment on different parameters

\begin{tabular}{|c|c|c|}
\hline Parameters & $\begin{array}{c}\text { Difference of values from day } \\
0 \text { to day } 60 \text { in Boron-treated } \\
\text { calves }\end{array}$ & $\begin{array}{l}\text { Difference of values from } \\
\text { day } 0 \text { to day } 60 \text { in } \\
\text { tamarind-treated calves }\end{array}$ \\
\hline Plasma F (ppm) & $(-) 0.25 \pm 0.01^{\mathrm{A}}$ & $(-) 0.3 \pm 0.08^{\mathrm{B}}$ \\
\hline Urine F (ppm) & (-) $3.31 \pm 0.34$ & (-) $3.58 \pm 0.23$ \\
\hline Faecal F (ppm) & (+) $4.94 \pm 0.64$ & $(+) 4.8 \pm 0.67$ \\
\hline Haemoglobin $(\mathrm{g} \%)$ & (+) $0.83 \pm 0.25^{\mathrm{A}}$ & (+) $1.7 \pm 0.17^{\mathrm{B}}$ \\
\hline Total leucocyte count $\left(10^{3} / \mathrm{mm}^{3}\right)$ & (+) $0.23 \pm 0.09^{\mathrm{A}}$ & $(+) 0.7 \pm 0.16^{\mathrm{B}}$ \\
\hline Packed cell volume (\%) & (+) $2.33 \pm 0.55^{\mathrm{A}}$ & (+) $4.83 \pm 0.47^{\mathrm{B}}$ \\
\hline Calcium (mg/dl) & (+) $1.16 \pm 0.09^{\mathrm{A}}$ & (+) $1.47 \pm 0.08^{\mathrm{B}}$ \\
\hline Phosphorus (mg/dl) & (-) $1.14 \pm 0.1$ & $(-) 1.34 \pm 0.06$ \\
\hline Alkaline phosphatase (IU/L) & (-) $11.15 \pm 0.2$ & (-) $12.6 \pm 0.3$ \\
\hline Aspartate transaminase (IU/L) & $(-) 16.08 \pm 0.37^{\mathrm{A}}$ & (-) $20.72 \pm 0.43^{\mathrm{B}}$ \\
\hline Total Protein $(\mathrm{gm} / \mathrm{dl})$ & (+) $0.15 \pm 0.02^{\mathrm{A}}$ & $(+) 0.36 \pm 0.04^{\mathrm{B}}$ \\
\hline Albumin (gm/dl) & (+) $0.04 \pm 0.02$ & (+) $0.06 \pm 0.03$ \\
\hline Urea (mg/dl) & (-) $2.93 \pm 0.17^{\mathrm{A}}$ & (-) $3.75 \pm 0.11^{\mathrm{B}}$ \\
\hline Creatinine (mg/dl) & $(-) 0.12 \pm 0.02^{\mathrm{A}}$ & (-) $0.25 \pm 0.05^{\mathrm{B}}$ \\
\hline
\end{tabular}

The values (mean $\pm \mathrm{SE}, \mathrm{n}=6$ ) bearing dissimilar superscripts (capital letters in a row) differ significantly at $\mathrm{P}<0.05$.

"+" sign indicates increment in value from day 0 to day 60 whereas " -" sign indicates reduction in value from day 0 to day 60

Table.4 Haematological parameters in calves from both less exposed and fluorotic area at different observation periods

\begin{tabular}{|c|c|c|c|c|}
\hline Parameter & Group & Day 0 & Day 30 & Day 60 \\
\hline \multirow{4}{*}{$\begin{array}{l}\text { Haemoglobin } \\
(\mathrm{g} \%)\end{array}$} & Group I & $11.00 \pm 0.32^{\mathrm{B}}$ & $11.13 \pm 0.25^{B}$ & $11.10 \pm 0.28^{\mathrm{D}}$ \\
\hline & Group II & $7.86 \pm 0.22^{\mathrm{A}}$ & $7.83 \pm 0.19^{\mathrm{A}}$ & $7.58 \pm 0.16^{\mathrm{A}}$ \\
\hline & Group III & $7.70 \pm 0.22^{\mathrm{aA}}$ & $7.97 \pm 0.18^{\mathrm{aA}}$ & $8.53 \pm 0.07^{\mathrm{bB}}$ \\
\hline & Group IV & $7.73 \pm 0.11^{\mathrm{aA}}$ & $7.87 \pm 0.08^{\mathrm{aA}}$ & $9.43 \pm 0.08^{\mathrm{bC}}$ \\
\hline \multirow{4}{*}{$\begin{array}{l}\text { Total leucocyte count } \\
\qquad\left(10^{3} / \mathrm{mm}^{3}\right)\end{array}$} & Group I & $9.80 \pm 0.20^{\mathrm{B}}$ & $9.53 \pm 0.31^{\mathrm{B}}$ & $9.35 \pm 0.36^{\mathrm{C}}$ \\
\hline & Group II & $6.95 \pm 0.14^{\mathrm{A}}$ & $6.67 \pm 0.3^{A}$ & $6.63 \pm 0.19^{\mathrm{A}}$ \\
\hline & Group III & $6.86 \pm 0.18^{\mathrm{A}}$ & $6.98 \pm 0.19^{\mathrm{A}}$ & $7.10 \pm 0.20^{\mathrm{AB}}$ \\
\hline & Group IV & $6.94 \pm 0.07^{\mathrm{aA}}$ & $7.33 \pm 0.13^{\mathrm{abA}}$ & $7.65 \pm 0.16^{\mathrm{bB}}$ \\
\hline \multirow{4}{*}{$\begin{array}{l}\text { Packed cell volume } \\
(\%)\end{array}$} & Group I & $32.83 \pm 0.98^{\mathrm{B}}$ & $33.5 \pm 0.76^{\mathrm{C}}$ & $33.3 \pm 0.88^{\mathrm{D}}$ \\
\hline & Group II & $23.50 \pm 0.76^{\mathrm{A}}$ & $23.5 \pm 0.56^{\mathrm{A}}$ & $23.17 \pm 0.48^{\mathrm{A}}$ \\
\hline & Group III & $23.17 \pm 0.54^{\mathrm{aA}}$ & $24 \pm 0.63^{\mathrm{abAB}}$ & $25.5 \pm 0.22^{\mathrm{bB}}$ \\
\hline & Group IV & $23.66 \pm 0.82^{\mathrm{aA}}$ & $23.67 \pm 0.82^{\mathrm{aAB}}$ & $28.5 \pm 0.22^{\mathrm{bC}}$ \\
\hline
\end{tabular}

The values (mean $\pm \mathrm{SE}, \mathrm{n}=6$ ) bearing no common superscript in small letters in a row and capital letters in a column differ significantly at $\mathrm{P}<0.05$.

Group I: Negativecontrol; Group II: Fluorotic calves; Group III: Fluorotic calves receiving boron; Group IV: Fluorotic calves receiving tamarind 
Table.5 Biochemical parameters in calves from both less exposed and fluorotic area at different observation periods

\begin{tabular}{|c|c|c|c|c|}
\hline Parameter & Group & Day 0 & Day 30 & Day 60 \\
\hline \multirow{4}{*}{$\begin{array}{l}\text { Calcium } \\
\text { (mg/dl) }\end{array}$} & I & $10.856 \pm 0.31^{\mathrm{B}}$ & $10.722 \pm 0.182^{C}$ & $10.761 \pm 0.189^{C}$ \\
\hline & II & $6.855 \pm 0.147^{\mathrm{A}}$ & $6.766 \pm 0.103^{A}$ & $6.745 \pm 0.134^{\mathrm{A}}$ \\
\hline & III & $7.037 \pm 0.064^{\mathrm{aA}}$ & $7.840 \pm 0.058^{\mathrm{bB}}$ & $8.197 \pm 0.112^{\mathrm{bB}}$ \\
\hline & IV & $7.031 \pm 0.058^{\mathrm{aA}}$ & $8.039 \pm 0.092^{\mathrm{bB}}$ & $8.497 \pm 0.059^{\mathrm{cB}}$ \\
\hline \multirow{4}{*}{$\begin{array}{l}\text { Phosphorus } \\
\text { (mg/dl) }\end{array}$} & I & $4.847 \pm 0.198^{\mathrm{A}}$ & $4.834 \pm 0.182^{\mathrm{A}}$ & $4.763 \pm 0.16^{\mathrm{A}}$ \\
\hline & II & $7.053 \pm 0.084^{B}$ & $7.015 \pm 0.033^{C}$ & $7.042 \pm 0.09^{C}$ \\
\hline & III & $7.133 \pm 0.092^{\mathrm{bB}}$ & $6.265 \pm 0.18^{\mathrm{aB}}$ & $5.985 \pm 0.091^{\mathrm{aB}}$ \\
\hline & IV & $7.126 \pm 0.074^{\mathrm{cB}}$ & $6.177 \pm 0.141^{\mathrm{bB}}$ & $5.783 \pm 0.066^{\mathrm{aB}}$ \\
\hline \multirow{4}{*}{$\begin{array}{c}\text { Alkaline } \\
\text { phosphatase } \\
\text { (IU/L) }\end{array}$} & I & $150.997 \pm 1.007^{\mathrm{A}}$ & $147.12 \pm 1.051^{\mathrm{A}}$ & $144.447 \pm 0.903^{\mathrm{A}}$ \\
\hline & II & $185.983 \pm 0.622^{B}$ & $190.329 \pm 1.300^{\mathrm{C}}$ & $193.39 \pm 1.170^{\mathrm{C}}$ \\
\hline & III & $185.35 \pm 0.940^{\mathrm{cB}}$ & $179.224 \pm 0.860^{\mathrm{bB}}$ & $174.21 \pm 0.890^{\mathrm{aB}}$ \\
\hline & IV & $185.639 \pm 1.410^{\mathrm{cB}}$ & $178.673 \pm 2.020^{\mathrm{bB}}$ & $173.089 \pm 1.930^{\mathrm{aB}}$ \\
\hline \multirow{4}{*}{$\begin{array}{c}\text { Aspartate } \\
\text { transaminase } \\
\text { (IU/L) }\end{array}$} & I & $51.790 \pm 1.415^{\mathrm{A}}$ & $52.074 \pm 1.401^{\mathrm{A}}$ & $52.349 \pm 1.432^{\mathrm{A}}$ \\
\hline & II & $87.271 \pm 0.621^{\mathrm{B}}$ & $87.498 \pm 0.619^{\mathrm{D}}$ & $87.584 \pm 0.590^{\mathrm{D}}$ \\
\hline & III & $86.375 \pm 0.552^{\mathrm{cB}}$ & $79.216 \pm 0.405^{\mathrm{bC}}$ & $70.300 \pm 0.458^{\mathrm{aC}}$ \\
\hline & IV & $86.956 \pm 0.69^{\mathrm{cB}}$ & $75.387 \pm 0.378^{\mathrm{bB}}$ & $66.251 \pm 0.238^{\mathrm{aB}}$ \\
\hline \multirow{4}{*}{$\begin{array}{l}\text { Total Protein } \\
\text { (gm/dl) }\end{array}$} & I & $7.062 \pm 0.130^{B}$ & $7.083 \pm 0.119^{\mathrm{B}}$ & $7.093 \pm 0.135^{\mathrm{C}}$ \\
\hline & II & $6.500 \pm 0.127^{\mathrm{A}}$ & $6.368 \pm 0.165^{\mathrm{A}}$ & $6.257 \pm 0.159^{\mathrm{A}}$ \\
\hline & III & $6.553 \pm 0.172^{\mathrm{A}}$ & $6.642 \pm 0.179^{\mathrm{AB}}$ & $6.705 \pm 0.166^{\mathrm{ABC}}$ \\
\hline & IV & $6.485 \pm 0.102^{\mathrm{aA}}$ & $6.653 \pm 0.101^{\mathrm{abAB}}$ & $6.848 \pm 0.114^{\mathrm{bBC}}$ \\
\hline \multirow{4}{*}{$\begin{array}{l}\text { Albumin } \\
\text { (gm/dl) }\end{array}$} & I & $3.662 \pm 0.035^{\mathrm{B}}$ & $3.576 \pm 0.038^{\mathrm{B}}$ & $3.514 \pm 0.063^{B}$ \\
\hline & II & $3.130 \pm 0.082^{\mathrm{A}}$ & $3.081 \pm 0.096^{\mathrm{A}}$ & $3.025 \pm 0.105^{\mathrm{A}}$ \\
\hline & III & $2.972 \pm 0.078^{\mathrm{A}}$ & $2.993 \pm 0.084^{\mathrm{A}}$ & $3.016 \pm 0.091^{\mathrm{A}}$ \\
\hline & IV & $3.005 \pm 0.073^{\mathrm{A}}$ & $3.026 \pm 0.068^{\mathrm{A}}$ & $3.062 \pm 0.065^{\mathrm{A}}$ \\
\hline \multirow{4}{*}{$\begin{array}{l}\text { Urea } \\
(\mathbf{m g} / \mathbf{d l})\end{array}$} & I & $27.983 \pm 0.879^{\mathrm{A}}$ & $28.166 \pm 0.742^{\mathrm{A}}$ & $27.573 \pm 0.526^{\mathrm{A}}$ \\
\hline & II & $36.272 \pm 1.833^{\mathrm{B}}$ & $37.813 \pm 1.931^{\mathrm{C}}$ & $37.775 \pm 1.106^{\mathrm{C}}$ \\
\hline & III & $36.437 \pm 0.974^{\mathrm{B}}$ & $34.688 \pm 1.094^{\mathrm{B}}$ & $33.505 \pm 1.070^{\mathrm{B}}$ \\
\hline & IV & $36.880 \pm 1.375^{\mathrm{B}}$ & $34.414 \pm 1.525^{\mathrm{B}}$ & $33.134 \pm 1.433^{\mathrm{B}}$ \\
\hline \multirow{4}{*}{$\begin{array}{c}\text { Creatinine } \\
(\mathrm{mg} / \mathrm{dl})\end{array}$} & I & $1.133 \pm 0.078^{\mathrm{A}}$ & $1.160 \pm 0.056^{\mathrm{A}}$ & $1.178 \pm 0.049^{\mathrm{A}}$ \\
\hline & II & $1.834 \pm 0.111^{\mathrm{B}}$ & $1.860 \pm 0.108^{\mathrm{B}}$ & $1.890 \pm 0.096^{\mathrm{B}}$ \\
\hline & III & $1.880 \pm 0.072^{\mathrm{B}}$ & $1.805 \pm 0.067^{\mathrm{B}}$ & $1.763 \pm 0.054^{\mathrm{B}}$ \\
\hline & IV & $1.958 \pm 0.045^{\mathrm{bB}}$ & $1.881 \pm 0.044^{\mathrm{abB}}$ & $1.710 \pm 0.058^{\mathrm{aB}}$ \\
\hline
\end{tabular}

The values (mean $\pm \mathrm{SE}, \mathrm{n}=6$ ) bearing no common superscript in small letters in a row and capital letters in a column differ significantly at $\mathrm{P}<0.05$.

Group I: Negative control; Group II: Fluorotic calves; Group III: Fluorotic calves receiving boron; Group IV: Fluorotic calves receiving tamarind

The surface water had higher $\mathrm{F}$ than ground water due to contamination by sewage, sludge, fumes and suspended particulate matters released from the smelter which were gradually deposited on water bodies. This is contrary to the picture of hydrofluorosis, where the F concentration of ground water was much higher as a result of geothermal 
activity rather than industrial contamination (Maiti et al., 2003). The green fodder contained less $\mathrm{F}$ than dry fodder due to low dry matter content and high moisture content. The dietary intake of animals and the concentration of $\mathrm{F}$ in diet largely affect the degree of fluorosis. However, the present study was conducted on farm-based animals (suffering from industrial fluorosis) which were mostly maintained on grazing with little supplementation dry fodder, hence the minor variations in diet could not be studied.The plasma $F$ level of calves within a $3 \mathrm{~km}$ radial distance from the smelter plant was above the normal level of $0.2 \mathrm{ppm}$ as stated by Radostits et al. (2009) and also much higher than the unpolluted area. The WHO (2006) has set the guideline value at $1.5 \mathrm{mg} / \mathrm{L}$ of $\mathrm{F}$, but mild forms of dental fluorosis begin to occur at lower levels (Hussain et al., 2005).

\section{Efficacious treatment of tamarind for ameliorating fluorosis compared to boron}

In the present investigation, elevated levels of plasma $\mathrm{F}$, urine $\mathrm{F}$ and faecal $\mathrm{F}$ were observed in fluorotic calves than calves from low $\mathrm{F}$ area. Significant reduction of plasma $F$ following 60 days of $\mathrm{B}$ administration was due to formation of Boron-Fluoride complex $\left(\mathrm{BF}_{4}\right)$ in GI tract followed by its elimination in faeces (Elsair et al., 1980), thereby increasing the faecal $\mathrm{F}$ level. The decreased urinary excretion of $F$ following boron supplementation points to a reduction in $\mathrm{F}$ absorption from the gastrointestinal tract and resultant decreased excretion of $\mathrm{F}$ via kidney (Bharti et al., 2007).

Interference with $\mathrm{F}$ absorption from the gut due to administration of dried pulp of tamarind fruits might have played a role in reducing plasma $\mathrm{F}$ concentrations as indicated by increased faecal $\mathrm{F}$ concentrations. There was also significant reduction in plasma $\mathrm{F}$ by tamarind pulp supplementation compared to
B. This property of tamarind can be attributed to high concentrations of minerals, like $\mathrm{Ca}$ and phosphorus, along with zinc, potassium and iron (Caluwe et al., 2010) which are reported to form many active insoluble complexes with $\mathrm{F}$ in gut. Tamarind fruit is also rich in tannin and fiber (Khandare et al., 2002) which would have helped in enhancing $F$ elimination in faeces and in reducing absorption, resulting in lower bioavailability and concomitantly lower urinary loss. On the contrary enhanced urinary $\mathrm{F}$ excretion by the use of tamarind pulp extract was reported in dogs (Khandare et al., 2000), human (Khandare et al., 2002) and rats (Dey et al., 2011) though examination of faecal $F$ levels were not included in these studies.

The presence of anemia in F-affected animals was also reported in calves (Bharti et al., 2007), buffaloes (Swarup and Singh 1989) and cows (Singh and Swarup 1994 and Mandal et al., 2015) whereas decrease in TLC was previously observed by Behera (1993) and Swarup and Singh (1989) in cattle. On the contrary, leucocytosis was observed in Finduced buffalo calves by Gill and Dumka (2013). F-induced disorders in hematopoietic organs in mice and in human hematopoietic progenitor cells have also been recorded (Machalinska et al., 2002). These facts might have resulted in anaemia and leucopenia in fluorotic calves in the present investigation. The lower $\mathrm{Hb}$ level may possibly be due to toxic effect of $\mathrm{F}$ on the serum level of iron and poor retention of iron (Hoogstratten et al., 1965). Significant PCV changes in the study were also due to toxic effects of $F$ on the RBC cell membrane and subsequently shrinkage of cell. In the present investigation, the higher $\mathrm{Hb}$ and PCV values after 60 days of treatment might be due to prevention of oxidative damage to cell membrane of $\mathrm{RBC}$ by $\mathrm{B}$ (Bharti et al., 2007) in B supplementation group, though it failed to exert any significant effect on the TLC level. But more significant 
increase in the above parameter along with TLC in tamarind supplementation group might be due to high iron and antioxidant like polyphenols and flavanoids, reported to be present in tamarind (Martinello et al., 2006). Similar reports of improved haematological parameters was also reported by Mandal et al., (2015) after feeding of Moringa oleifera fruit powder in fluorotic calves due to reduced fluoride load in plasma.

A significantly lower $\mathrm{Ca}$ in fluorotic calves as compared to negative control was probably because of the decrease in absorption in addition to enhanced excretion of $\mathrm{Ca}$ via urine (Bharti et al., 2007). Moreover, decrease in Ca-ATPase activity was responsible for increase in urinary Ca causing hypocalcaemia (Singh and Swarup 1999). However, supplementation of B to the fluorotic animals produced significantly higher $\mathrm{Ca}$ concentration at the end of experiment due to its protective effect against the inhibitory effect of $\mathrm{F}$ on $\mathrm{Ca}$-ATPase in renal tissues. But, supplementation of dried fruit pulp of tamarind was more efficient in increasing $\mathrm{Ca}$ concentration in blood which might be due to its richness in Ca (Ishola et al., 1990) and increase in elimination of $\mathrm{F}$ from the body.

The average serum phosphorus content of fluorotic calves was found to be more than the normal value. This is because the circulatory parathormone level increases in $\mathrm{F}$ intoxication (Singh and Swarup 1999) which regulates metabolism of $\mathrm{Ca}$ and phosphorus causing hyperphosphatemia due to concurrent hypocalcemia. However, contradictory hypophosphoraemia was observed in fluorotic cattle by Mehedintu et al., (2000).

Treatment with B and tamarind pulp significantly lowered the phosphorus level which is in accordance with Bharti et al., (2007) and Gupta et al., (2013), respectively.

ALP activity was significantly higher in fluorotic calves as compared to those from the low $\mathrm{F}$ area. It is almost a consistent finding in natural and experimental fluorosis (Jagadish et al. 1998; Maiti and Das 2004). Since F stimulates osteoblastic activity and causes lysis of osteocyte (Araya et al., 1990), the increase in ALP can be related to bone changes associated with increased $F$ in the serum (Farley et al., 1987). The protective effect of B on bone and teeth deformation can be assumed from the lower serum activity in fluorotic calves supplied with B. Tamarind pulp also significantly lowered the ALP in the fluorotic calves. The beneficial effect of tamarind on alkaline phosphatase activity might be due to high $\mathrm{Ca}$ content in the dried pulp (Gopalan et al., 1982; Ishola et al., 1990).

Significantly higher plasma AST and lower total protein and albumin, indicative of hepatic dysfunction, might be due to hepatotoxic effect of $\mathrm{F}$ compounds (Jagadish et al., 1998; Singh et al., 2002). There was significantly lower AST level upon treatment with $B$ which might be due to decreased plasma $F$ burden, thereby reversing the hepatic metabolic status. The anti-oxidative property of $\mathrm{B}$ might also contribute this change. But the amount of $\mathrm{B}$ fed to the fluorotic calves might not be sufficient enough to elicit any significant alteration in plasma total protein and albumin level. Supplementation of tamarind pulp powder significantly decreased the AST level and increased the total protein in plasma. It has been reported that Tamarindus indica contains flavanoids, $\beta$-carotenes and ascorbic acid (Caluwe et al., 2010) which have hepatoprotective effect (Pimple et al., 2007).

There was a significantly higher level of urea and creatinine in the fluorotic calves than the calves from low $\mathrm{F}$ zone (Metwalli et al., 1995; Sharma et al., 2010), indicative of degenerative changes in the kidney (Singh and Swarup 1999). Kidneys play an important 
role in regulation of total body $\mathrm{F}$ burden, and toxic doses of $\mathrm{F}$ can result in renal dysfunction by inhibiting various enzyme systems in the kidneys. This increased level might also be due to catabolism of protein because of partial starvation in affected animals (Swarup et al., 2001).

Consequently, both the treatments tended to decrease urea and creatinine levels, tamarind more so than B, but that only tamarind decreased creatinine levels significantly below day 0 levels. This might be due to antioxidative property of tamarind which protects renal and muscular damage. Tamarind also contains $\mathrm{Ca}$ and ascorbic acid which were reported to cause inhibition of phosphodiasterase, thereby augmenting cAMP levels that are involved in the activation of several phsophokinase in liver and muscle (Chinoy et al., 1993). In the present study both tamarind and B supplementation exerted beneficial effect on $F$ concentrations in biological samples and also on haematobiochemical parameters, but tamarind seemed to be more potent than that of B. But as the study was based on grazing animals which were also provided with supplementary feeding (other than treatments), there might be minor differences in $\mathrm{F}$ intake. So a meager possibility of biasness in result may not be excluded.

In conclusion, the present study revealed toxic levels of $\mathrm{F}$ in environmental samples within $3 \mathrm{~km}$ radial distance of $\mathrm{Al}$ smelter plant, for which grazing of livestock in this area should be avoided as far as possible and provision of ground water(such as deep well or bore well) as drinking water should be practised. In this study, changes in F level in bio-samples and restoration of haemato-biochemical parameters after supplementation with tamarind pulp to calves suggest that this compound may play a beneficial role in reducing $\mathrm{F}$ exposure and the risk of juvenile fluorosis and its progression.

\section{Acknowledgment}

Financial support provided by University Grant Commission in terms of Major Research Project to the Dr R. C. Patra, Principal Investigator is thankfully acknowledged.

\section{Declaration of Interest}

The authors declare that there is no conflict of interest.

\section{References}

AOAC. 1995. Official Methods of Analysis. 15th ed. Washington: Association of Official Analytical Chemists.

Araya, O., F. Wittwer, A. Villa, and C. Ducom. 1990. Bovine fluorosis following volcanic activity in the Southern Andes. Veterinary record.126: 641-642.

Benzamin, M.M. 1985. Outline of veterinary clinical pathology. 3rd ed. New Delhi: Kalyani Publishers.

Bharti, V.K., M. Gupta, D. Lall, and V. Kapoor. 2007. Effects of boron on haemogram and biochemical profile of urine in buffalo calves fed a high fluoride ration. Fluoride.40: 238-43.

Caluwe, E.D., K. Halamova, and P.V. Damme. 2010. Tamarindus indica L.- A review of traditional uses phytochemistry and pharmacology. Africa Focus. 23: 53-83.

Cernik, A.A., J.A. Cooke, and R.J. Hall. 1970. Specific ion electrode in the determination of urinary fluoride. Nature. 227: 1260-1261.

Chinoy, N.J., M. Sharma, and M. Michael. 1993. Beneficial effects of ascorbic acid and calcium on reversal of fluoride toxicity in male rats. Fluoride. 26: 45-56.

Choubisa, S.L. 1999. Chronic fluoride intoxication (fluorosis) in tribes and their domestic animals. International Journal of Environmental Studies. 56: 703-716. 
Dey, S., D. Swarup, A. Saxena, and A. Dan. 2011. In vivo efficacy of tamarind (Tamarindus indica) fruit extract on experimental fluoride exposure in rats. Research in Veterinary Science.91: 422425.

Elsair, J., R. Merad, R. Dennie, M. Reggabi, B. Alamir, S. Benali, M. Azzouz, and K. Khelfat. 1980. Boron as an antidote of acute and subacute fluoride intoxication in rabbits: its action on fluoride, calcium, phosphorus metabolism. Fluoride. 13: 129-138.

Ergun, H., H.A. Russel-Sinn, N. Baysu, andY. Dündar. 1987. Studies on the Fluoride Contents in Water and Soil,Urine, Bone, and Teeth of Sheep and Urine of Human from Eastern and Western Parts of Turkey. Deutsche Tierärztliche Wochenschrift. 94: 416-420.

Farley, S.M., J.E. Wergedal, L.C. Smith, M.W. Lundy, J.R. Farley, and D.J. Baylink. 1987. Fluoride therapy for osteoporosis: characterization of the skeletal response by serial measurements of serum alkaline phosphatase activity. Metabolism. 36: 211-218.

Gill, K.K., and V.K. Dumka. 2013. Haematological alteration induced by subchronic oral exposure of buffalo calves to fipronil and fluoride.Fluoride. 46: 65-72.

Gopalan, C., B.V. Ramasastri, and S.C. Balasubramanium. 1982. Nutritive value of Indian Foods. NIN, ICMR, Hyderabad, India: 85.

Gupta, A. R., S. Dey, D. Swarup, M. Saini, A. Saxena, and A. Dan. 2013.Ameliorative effect of Tamarindusindica L. on biochemical parameters of serum and urine in cattle from fluoride endemic area.Veterinarskiarhiv.83: 487-496.

Han, B.,, and Y. Shi. 2001. Studies on the alleviation of bovine endemic fluorosis. Journal of Yangzhou University (Natural Science Edition)(issue 2) 31-34.

Hoogstratten, B., N.C. Leone, J.L. Shupe, D.A. Greenwood, and L. Lieberman. 1965. Effect of fluorides on hemopoietic system, liver and thyroid gland in cattle. Journal of the American Medical Association. 192: 26-32.

Hussain, J., K.C. Sharma, and I. Hussain. 2005. Fluoride Distribution in Groundwater of Banera Tehsil in Bhilwara District, Rajasthan. Asian Journal of Chemistry. 17: 457-461.

Ishola, M.M., E.B. Agbaji, and A.S. Agbaji. 1990. A Chemical Study of Tamarindus indica (Tsamiya) Fruits Grown in Nigeria. Journal of the Science of Food and Agriculture.51: 141-143.

Jain, S. K. 2000. Plants in Indian ethnoveterinary medicine: Status and prospects. Indian Journal of Veterinary Medicine. 20: 1-11.

Kessabi, M., A. Hamliri, and J. P. Braun. 1986. Experimental fluorosis in sheep. Alleviating effects of aluminium. Veterinary and Human Toxicololgy.28: 300-304.

Khandare, A.L., P.U. Kumar, and N. Lakshmaiah. 2000. Beneficial effect of Tamarind ingestion on Fluoride toxicity in dogs. Fluoride. 33: 33-38.

Khandare, A.L., G.S. Rao, and N. Lakshmaiah. 2002. Effect of tamarind ingestion on fluoride excretion in humans. European Journal of Clinical Nutrition. 56: 82-85.

Machalinska, A., B. Wiszniewska, J. Tarasiuk, and D. Machalinski. 2002. Morphological effect of sodium fluoride on hematopoetic organs in mice. Fluoride. 35: 231-238.

Maiti, S.K., and P.K. Das. 2004. Biochemical Changes in Endemic Dental Fluorosis in Cattle. Indian Journal of Animal Science. 74: 169-171.

Maiti, S.K., P.K. Das, and S.K. Ray. 2003. Effect of endemic fluorosis on haemogram of cattle and goat. Indian Journal of Veterinary Medicine.23: 34-7.

Mandal, K.D., Das, M.R., Pati, M., Pati, P.D., Gupta, A.R., Patra, R.C. and Senapati, S.K., 2015. Effect of Moringa oleifera on hematological parameters of calves reared in industrial fluorotic area. Veterinary World. 8(11):1364-1369. 
Martinello, F., S.M. Soares, J.J. Franco, A.C. Santos, A. Sugohara, S.B. Garcia, C. Curti, and S.A. Uyemura. 2006. Hypolipemic and antioxidant activities from Tamarindus indica $\mathrm{L}$ pulp fruit extract in hypercholesterolemic hamsters. Food and Chemical Toxicology. 44: 810818.

Mehedintu, C., N. Avram, N. Medrea, and C. Dulescu. 2000. Fluoride values in biochemical fluids and paraclinical changes in industrial fluorosis of ruminants. Studies and Research in Veterinary. Medicine. 8: 89-90.

Metwalli, A.A., S.A. EL-Gharieb, and K.M. Ashry. 1995. Clinical and laboratory investigations on chronic bovine fluorosis. Proceedings of the Third Scientific Congress Egyptian Society for Cattle Diseases. 2: 331-335.

Patra, R. C., S. K. Dwivedi, B. Bhardwaj and D. Swarup. 2000. Industrial fluorosis in cattle and buffalo around Udaipur, India. Science of the Total Environment. 253: 145-150.

Pimple, B.P., P.V. Kadam, N.S. Badgujar, A.R. Bafna, and M.J. Patil. 2007. Protective effect of Tamarindus indica (Linn) against paracetamol-induced hepatotoxicity in rats. Indian Journal of Pharmaceutical Science. 69: 827-831.

Ranjan, R., D. Swarup, R.C. Patra, and V. Chandra. 2009. Tamarindus indica L. and Moringa oleifera M. extract administration ameliorate fluoride toxicity in Rabbits. Indian Journal of Experimental Biology.47: 900-905.
Sharma, S.P., S.S. Randhawa, S.K. Uppal, N. Saini, and R.S. Brar. 2010. Haematobiochemical profile in fluorosis affected buffaloes.Indian Veterinary Journal.87: 827-828.

Shupe, J. L. 1980. Clinicopathological features of fluoride toxicosis in cattle. Journal of. Animal Science.51: 746-758.

Singh, J. L. and D. Swarup, 1994.Fluorosis in buffaloes. Veterinary Record. 135: 260261.

Singh, J. L. and D. Swarup. 1999. Biochemical changes in serum and urine bovine fluorosis. Indian Journal of Animal Science.69: 776-778.

Singh, P.K., N. Sahoo, and S.K. Ray. 2002. Clinico-pathological features of fluorosis in goats.Indian Veterinary Journal. 79: 776-779.

Swarup, D. and Y. P. Singh.1989. Bovine fluorosis in a brick kiln congested zone. Indian Journal of Veterinary Medicine.9: 12-14.

Swarup, D., S.K. Dwivedi, S. Dey, and S. K. Ray. 1998. Fluoride intoxication in bovines due to industrial pollution. Indian Journal of Animal Science.68: 605-608.

Swarup, D., S. Dey, R.C. Patra, S.K. Dwivedi, and S.L. Ali. 2001. ClinicoEpidemiological Observations of Industrial Bovine Fluorosis in India. Indian Journal of Animal Science. 71: $1111-1115$

WHO. 2006. Fluoride in Drinking Water, 144. London: IWA.

\section{How to cite this article:}

Mirashree Pati, Ghana Syam Parida, Kruti Debnath Mandal, Amit Raj Gupta and Ramesh Chandra Patra. 2020. Comparative Ameliorative Efficacy of Tamarind Pulp against Boron on Fluorotic Calves Reared in Periphery Villages of Aluminium Smelter Plant Int.J.Curr.Microbiol.App.Sci. 9(07): 1254-1264. doi: https://doi.org/10.20546/ijcmas.2020.907.144 